\title{
Nonwoven Bio-Based Membranes for Removal of Micropollutants from Aqueous Water
}

\author{
ECATERINA MATEI ${ }^{1}$, CRISTINA ILEANA COVALIU ${ }^{1 *}$, GEORGE COMAN ${ }^{1 *}$, \\ MIHAI NEGROIU ${ }^{1}$, MARIA RAPA ${ }^{1}$, ANDRA-MIHAELA PREDESCU ${ }^{1}$, \\ ANDREI-CONSTANTIN BERBECARU ${ }^{1}$, CRISTIAN PREDESCU ${ }^{1}$, DUMITRU VAJU ${ }^{2}$, \\ VLAD GRIGORE ${ }^{2}$ \\ ${ }^{1}$ University Politehnica of Bucharest, 313 Splaiul Independenței, 060042, Bucharest, Romania \\ ${ }^{2}$ SC ICPE SA Bistrita, 7 Parcului Str., 13355153, Bistrita, Bistrita-Nasaud, Romania
}

\begin{abstract}
The aim of this paper is to obtain two types of bio-based membranes by electrospinning process: one based on polylactic acid (PLA), and PLA/polyhydroxybutyrate (PHB), and the second by coating the PLA/PHB membrane with chitosan (CS) and CS/activated coal (AC), respectively for removal of micropollutants from aqueous water. The designed bio-based electrospun membranes were analyzed through scanning electron microscopy (SEM), attenuated total reflectance (ATR) - Fourier transform infrared spectroscopy (FT-IR), differential scanning calorimetry (DSC), the removal of solid suspension and $\mathrm{Pb}$ (II) from aqueous water. The quality of filtrates was evaluated by physical-chemical methods, while the retaining of $\mathrm{Pb}$ (II) from wastewaters was reported.
\end{abstract}

Keywords: bio-based polymers, chitosan, activated coal, electrospinning, membrane, micropollutant, heavy metals

\section{Introduction}

The rapid growth of global population, generation of large quantities of wastewaters from industrial activities as well its needs for safe drinking water have become a critical issue that the word is facing. To obtain an acceptable quality of treated wastewaters, the removal of undesirables components, such as: conventional pollutants (suspended solids, colloids, inorganic salts and toxic substances and pathogens), and emerging contaminants (pharmaceuticals, personal care products, pesticides, degradation by-products of detergents, and endocrine disrupting compounds) should be provided [1-2]. Organic and inorganic pollutants found in wastewaters are bioactive and persistent contaminants, nonbiodegradable, which cannot be completely removed with traditional wastewater treatment methods. The presence of micropollutants in wastewater can lead to long-term hazards, as contaminants accumulate and can even form new mixtures in water [3]. It was found that the filtration membranes can be successfully used to retain contaminants from water. There are known three main types of membrane filtration systems: ceramic, metal and polymeric membranes [4]. Based on their separation principles, the filter membranes are classified in: reverse osmosis (RO), ultrafiltration (UF), nanofiltration (NF), and microfiltration (MF) [5]. Depending on the particle retention diameter, the pore diameter of the filter membranes are ranged from 0.05 to $10 \mu \mathrm{m}$ for MF, 0.1 to $0.005 \mu \mathrm{m}$ for UF, 0.5 to $5 \mathrm{~nm}$ for NF and 0.1 up to $1 \mathrm{~nm}$ for RO.

Microfiltration polyurethane-cellulose acetate membrane with a pore dimension of $0.86 \mu \mathrm{m}$ was studied for removal of Direct Blue dye (DB) from water [6]. The polysulfone type ultrafiltration membrane filtration process was used to evaluate the efficiency of removal of $\mathrm{TiO}_{2}, \mathrm{ZnO}$ and $\mathrm{CeO}_{2}$ nanoparticles with dimensions in the range of $10 \mathrm{~nm}$ to $21 \mathrm{~nm}$ from aqueous suspensions [7]. An efficiency of 72.3-98.6\% was reported for the retention of the investigated nanoparticles.

*email: cristina_covaliu@yahoo.com,george.coman1988@yahoo.com 
Polymeric nanofibers produced by the electrospinning process are the best materials for a variety of high value applications, including filtering pollutants from water [8-9], materials for optical and chemical detection [10], photovoltaic cells [11], tissue engineering [12] and drug controlled release [13], due to their very fine size and high surface-to-volume ratio.

Furthermore, the nanofibrous polymer membranes show higher porosity, interconnected pore structure, less energy for their producing and reduced cost of filtration as compared to conventional membranes [14]. It has been reported that the nonwoven polymeric membranes could be used both in filtration and adsorption of heavy metals [15-16]. For example, polymeric membranes with a diameter of about $100 \mathrm{~nm}$ obtained from recycled polyethylene terephthalate (PET) designed for water filtration have been obtained by electrospinning [17]. In another paper, the filtration efficiency of PET membranes was evaluated for retaining of latex beads, with dimensions ranging between $30 \mathrm{~nm}$ to $2000 \mathrm{~nm}$. It has been reported that over $99 \%$ of latex beads smaller than $500 \mathrm{~nm}$ were retained using gravitational filtering. Furthermore, a commercial polysulfone membrane was used to retain organic pollutants generated by residues from fish feed, manure and/or microorganisms in aquaculture systems [18]. Kampalanonwat and Supaphol [19] described the preparation of polyacrylonitrile (PAN) nanofiber mats by electrospinning, their modification with diethylenetriamine (DETA) and the successfully adsorption of $\mathrm{Cu}$ (II), $\mathrm{Pb}$ (II), Fe (II) and $\mathrm{Ag}$ (I) ions.

Nowadays, a considerable attention is paid towards the development of advanced filtering systems based on environment-friendly polymers in order to achieve high micropollutant removal efficiency. In addition to their biodegradation, the bio-based polymers such as polylactic acid (PLA) [20] and poly(hydroxybutyrate) (PHB) [21] have been studied for manufacturing of electrospun membranes with high mechanical strength, thermal stability and chemical resistance. PLA is obtained from the controlled depolymerization of the lactic acid monomer resulting from the fermentation of corn, sugars, starches, etc. It is one of the most promising biopolymers, biodegradable and compostable, with high transparency, water solubility resistance and good mechanical properties [22]. However, its dissolving in proper solvents and processability by electrospinning need to be improved. For this purpose it is recommended to blend PLA with other polymers or plasticizers [23]. PLA-based biomembranes and polyethylene glycol (PEG) were reported by electrospinning process and used for the absorption of pollutants found in drinking water [24]. Hydrophobic PLA nanofibers were found to have high efficiency for oil/water separation [25].

PHB belongs of the polyhydroxyalkanoate family (PHA) and it is an intensely designed polyester for environmental applications. It is totally biodegradable, partially crystalline, with a high melting temperature $\left(175^{\circ} \mathrm{C}\right)$ and a high degree of crystallinity [26-27]. PLA and PLA/PHB nonwoven polymeric membranes were also reported for oil adsorption from aqueous media [28].

Chitosan (CS) is a natural polymer obtained from crustaceans, showing biocompatibility, biodegradability, antimicrobial and antifungal activity [29]. Chitosan is insoluble in water and alkaline medium due to its rigid and compact crystalline structure and strong intra and intermolecular hydrogen bonds, but it is soluble only in acidic aqueous solutions with a $\mathrm{pH}$ of less than 6.5. Its chemical stability should be improved by the use of crosslinking agents, such as: glutaraldehyde, glycolic ether diglycidyl ethylene and epichlorohydrin [30]. The adsorption properties of chitosan were proved by our team for removal of $\mathrm{Cr}$ (VI) [31] and $\mathrm{Pb}$ (II) [32].

Activated carbon (AC) is used for water filters due to the fact that it is a natural and effective product for removing many toxins from water, such as volatile organic compounds and chlorine, without the need to use chemicals or remove mineral salts from the water.

The present study presents the obtaining of symmetric (PLA, PLA/PHB) and antisymetric (PLA/PHB/CS, PLA/PHB/CS/AC) nonwoven polymeric membranes in order to retain eighter the solid suspensions or heavy metals from aqueous water. 


\section{Materials and methods}

\subsection{Materials}

All used materials were analytical grade, thus:

- polylactic acid, PLA type 4032D (NatureWorks, Resinex SRL, Romania)

- polyhydroxybutyrate (PHB) in powder form (Biomer, Germany)

- $\quad$ chitosan powder with a deacetylation degree of 75\% (Aldrich-Sigma)

- $\quad$ activated carbon powder, 100-400 mesh (Sigma Aldrich).

Also solvents such as: dimethyl formamide (DMF), chloroform, acetic acid and a crosslinking agent - 50\% glutaraldehyde (Alfa Aesar, Germany).

\subsection{Preparing of Electrospun Bio-Based Membranes}

Polymeric solutions for electrospinning were obtained as follows:

- $10 \%$ PLA solution (wt/vol) was obtained by dissolving of PLA pellets in a mixture of solvents consisting of $90 \mathrm{wt} . \%$ chloroform and $10 \mathrm{wt} . \%$ DMF using a hot table with magnetic stirring at $90^{\circ} \mathrm{C}$, for $6 \mathrm{~h}$ and $600 \mathrm{rpm}$;

- 2.5\% PHB solution (wt/vol) was obtained by dissolving PHB powder in a mixture of 90 wt.\% chloroform and $10 \mathrm{wt} . \%$ DMF solvents using a hot table with magnetic stirring for $3 \mathrm{~h}$ at $50^{\circ} \mathrm{C}$.

- $1.5 \mathrm{wt} \%$ chitosan solution was obtained by dissolving of chitosan powder in $85 \%$ (vol/vol) acetic acid solution.

PLA/PHB solution was obtained by mixing $10 \%$ solution of PLA with $2.5 \%$ solution of PHB, as above prepared. The weight ratio between the PLA solution and that of PHB was 3:1.

The following experimental variants were prepared (Table 1).

Table 1. Experimental variants proposed for obtaining nonwoven bio-based membranes

\begin{tabular}{|c|c|c|c|c|}
\hline Sample & $\begin{array}{c}\text { PLA } \\
(\mathbf{w t} \%)\end{array}$ & $\begin{array}{c}\text { PHB } \\
(\mathbf{w t} \%)\end{array}$ & $\begin{array}{c}\text { CS } \\
(\mathbf{w t} \%)\end{array}$ & $\begin{array}{c}\text { AC } \\
(\mathbf{w t} \%)\end{array}$ \\
\hline PLA & 100 & & & \\
\hline PLA/PHB & 75 & 25 & & \\
\hline PLA/PHB/CS & 74.25 & 24.75 & 1 & 1 \\
\hline PLA/PHB/CS/AC & 73.5 & 24.5 & 1 & 1 \\
\hline
\end{tabular}

The nonwoven polymeric membranes were fabricated using a commercially TL-Pro-BM Electrospinning equipment (Tong Li Tech Co., Ltd., Bao An, Shenzhen, China), which consists of a syringe pump (TONG LI TECH device) with a volume of $50 \mathrm{~mL}$, a high-voltage power supplier, and a grounded conductive drum collector covered with aluminum foil. The optimal experimental conditions for obtaining of electrospun polymeric membranes are shown in Table 2.

Table 2. Optimal parameters of the electrospinning process for obtaining of nonwoven polymeric membranes

\begin{tabular}{|c|c|c|c|c|c|}
\hline Sample & $\begin{array}{c}\text { Negative electrode voltage } \\
(\mathbf{k V}) / \text { positive electrode } \\
\text { voltage }(\mathbf{k V})\end{array}$ & $\begin{array}{c}\text { Solution flow } \\
\text { rate }(\mathbf{m L} / \mathbf{h})\end{array}$ & $\begin{array}{c}\text { Distance } \\
\text { between the } \\
\text { needle to } \\
\text { collector }(\mathbf{c m})\end{array}$ & $\begin{array}{c}\text { Drum } \\
\text { rotation } \\
(\mathbf{r p m})\end{array}$ & $\begin{array}{c}\text { Drum rate } \\
(\mathbf{m} / \mathbf{s})\end{array}$ \\
\hline PLA & $-7.04 / 15.17$ & 0.9 & 12 & 250 & 10 \\
\hline PLA/PHB & $-8.42 / 24.02$ & 3.9 & 10 & 50 & 10 \\
\hline PLA/PHB/CS & $-10.4 / 21.37$ & 0.9 & 10 & - & - \\
\hline PLA/PHB/CS/AC & $-12.95 / 21.75$ & 0.7 & 10 & - & - \\
\hline
\end{tabular}

The experiments took place in the following environmental conditions: the temperature ranging from 20 to $28^{\circ} \mathrm{C}$ and a relative humidity of $27 \% \mathrm{RH}$. The membranes containing PLA/PHB/CS and $\mathrm{PLA} / \mathrm{PHB} / \mathrm{CS} / \mathrm{AC}$, respectively, were obtained by the depositing of $1 \%$ solution of CS, and 1:1 CS/AC, respectively onto the PLA/PHB membrane, previously obtained. The fabricated PLA/PHB/CS and 
PLA/PHB/CS/AC membranes were crosslinked by keeping them in contact with glutaraldehyde vapors (sol. 50\%) for $4 \mathrm{~h}$. Smooth polymeric membranes with a length of $\sim 12 \mathrm{~cm}$ and width of $\sim 6 \mathrm{~cm}$ were obtained by electrospinning.

\subsection{Characterization of Electrospun Bio-Based Membranes}

The polymeric membrane surfaces were investigated using a QUANTA 450 FEG (FEI, Eindhoven, The Netherlands) equipped with a field emission gun at a $1.2 \mathrm{~nm}$ resolution. Fourier transform infrared spectroscopy (FT-IR) with attenuated total reflectance (ATR) (Interspec 200-X Spectrophotometer. Interspectrum, Estonia) were applied to observe the functional groups presented in the electrospun polymeric membranes. Differential Scanning Calorimetry (DSC) measurements were determined using a Mettler Toledo (Model DSC 823 ${ }^{\mathrm{e}}$, Calorimeter (Greifensee, Zürich, Switzerland).

Specimens with dimensions (length $\mathrm{x}$ width) of $(6 \times 6) \mathrm{cm}^{2}$ were taken out from the PLA and PLA/PHB electrospun membranes and used for filtration of $25 \mathrm{~mL}$ solid suspension solution that contain $1 \%$ fine sand. This suspension is characterized by a $p \mathrm{H}$ value of 5.72 and electrical conductivity of 12.56 $\mu \mathrm{S} / \mathrm{cm}$. The filtrates from each electrospun polymeric membrane were collected and analyzed for the water quality constituents: the conductivity of the solution was measured using a Consort C862 equipment, $p \mathrm{H}$ was carried out by a Consort C 831 Multiparameter analyzer, under laboratory conditions, on duplicate, total content of dissolved soluble salts and transmittance measured using an UV-VIS Spectrometer (Alpha Helios, Thermospectronic). An analytical balance (accuracy $0.1 \mathrm{mg}$ ) was used to determine the filtration efficiency. Distilled water was used for comparison tests.

Adsorption capacity of PLA/PHB/CS and PLA/PHB/CS/AC electrospun membranes was investigated by contacting $100 \mathrm{mg}$ of adsorbent with $100 \mathrm{~mL}$ of $\mathrm{Pb}$ (II) solution at a concentration of 1 $\mathrm{mg} \mathrm{L}^{-1}$, with stirring $(200 \mathrm{rpm})$ at room temperature, for a maximum time of $120 \mathrm{~min}$. After reaching of equilibrium, the solutions were filtered (Whatman filter paper No. 1) and the $\mathrm{Pb}$ (II) concentration in the filtrate was detected at $217 \mathrm{~nm}$ wavelength by an atomic absorption spectrometer (GBC 932 AB PLUS, from GBC Scientific Equipment PTY Ltd., Australia) with acetylene flame.

\section{Results and discussions}

\subsection{Scanning electron microscope (SEM) measurement}

Structural investigation of the polymeric membranes obtained by the electrospinning process was performed by electron microscopy (SEM) analysis. In order to ensure the filtration of solutions contaminated with visible particles with the naked eye (with dimensions between $1 \mathrm{~mm}$ and $5 \mathrm{~mm}$ ) it is necessary that the pores of the membrane to be relatively evenly distributed and have an optimum diameter. The SEM images of the electrospun polymeric membranes are shown in Figure 1.

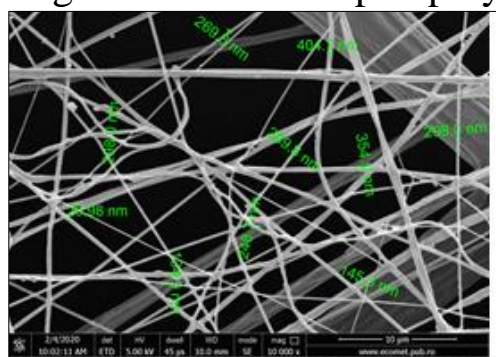

(a)

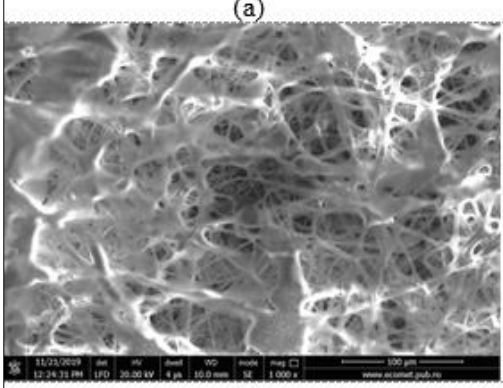

(c)

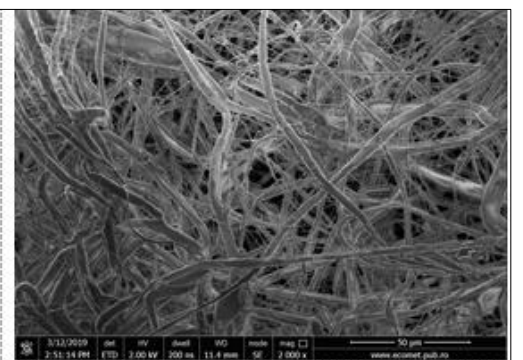

(b)

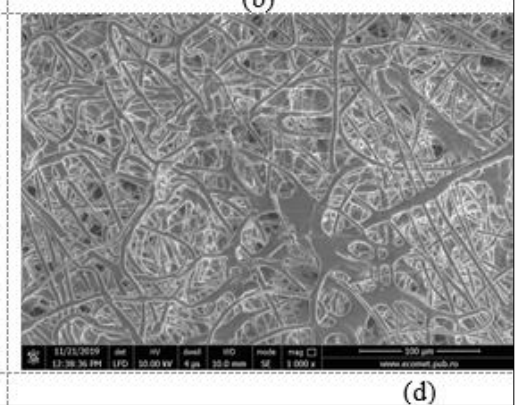




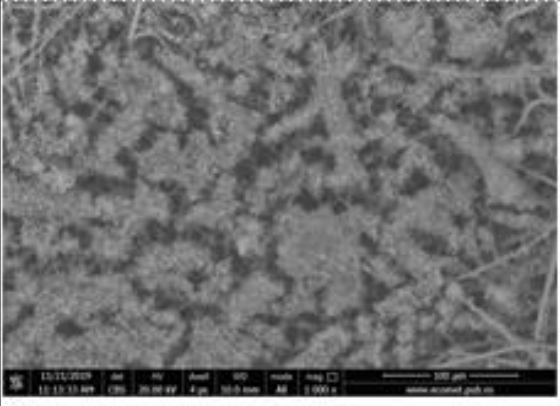

(e)

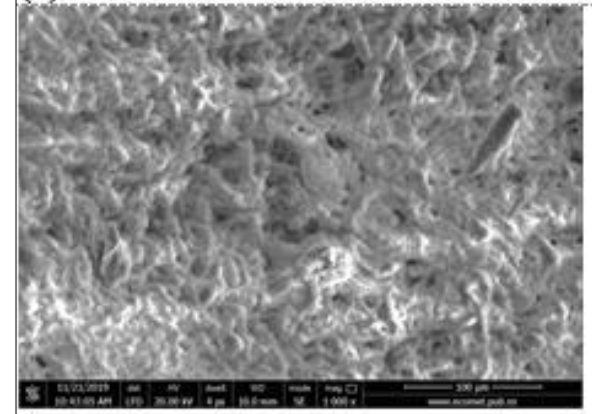

(g)

Fig

Figure 1. SEM images of the electrospun polymeric membranes:

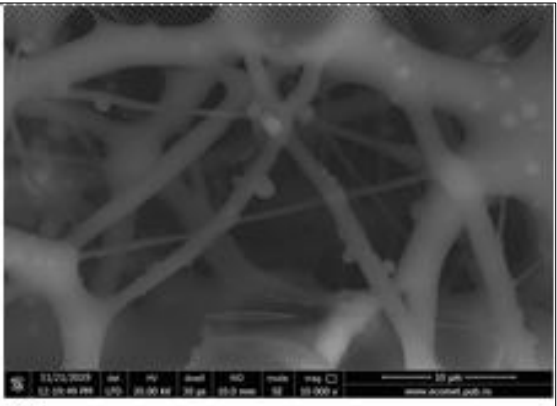

(f)

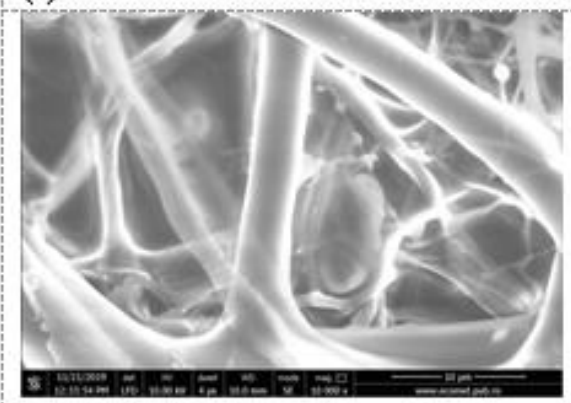

(h)

(a) PLA; (b) PLA/PHB; (c) PLA/PHB/CS; (d) PLA/PHB/CS crosslinked

(b) with glutaraldehyde; (e), (f) PLA/PHB/CS/AC; (g),

(c) (h) PLA/PHB/CS/AC crosslinked with glutaraldehyde

Consistency and diameter control, absence of any surface defects such as pores and "beads" as well as the continuity of unique nanofibers as much as possible represent optimal morphological characteristics that are achieved only by adjusting the electrospining parameters. The large diameter of electrospun fibers and the beads formation are related to the viscosity of solution. The right choice of ratio of 9:1 between chloroform and DMF solvents, the concentration of polymer solutions of $10 \%$ in the case of PLA and $2.5 \%$ in the case of PHB together with the selecting of electrospinning parameters according to Table 2 led to fabricate symmetric bio-based polymeric membranes. According to the SEM examination, it can be seen that the investigated polymeric membranes show a network of yarns with three-dimensional structure and intercalated pores. In the case of the PLA membrane (Figure 1 (a)) the nanofibers with a size diameter between $26-400 \mathrm{~nm}$ are observed. The pores have a size of $\sim 10 \mu \mathrm{m}$, which will ensure the retention of solid suspensions larger than $10 \mu \mathrm{m}$. A dense structure of nanofibers can be observed in the case of PLA/PHB membrane (Figure 1(b)). Large pores with diameter $\sim 20 \mu \mathrm{m}$ were observed in the case of asymmetric polymeric membranes, by deposition of CS and CS/AC, respectively, in the form of small spheres onto the PLA/PHB membrane (Figures 1(e-g)). The morphology of asymmetric membranes with large pores will allow the retention of micropollutants (heavy metals) only at the upper layer [33].

\subsection{Fourier Transform Infrared Spectroscopy (FT-IR)}

The ATR-FTIR spectra and optical images of polymeric nonwoven membranes are shown in Figure 2. 


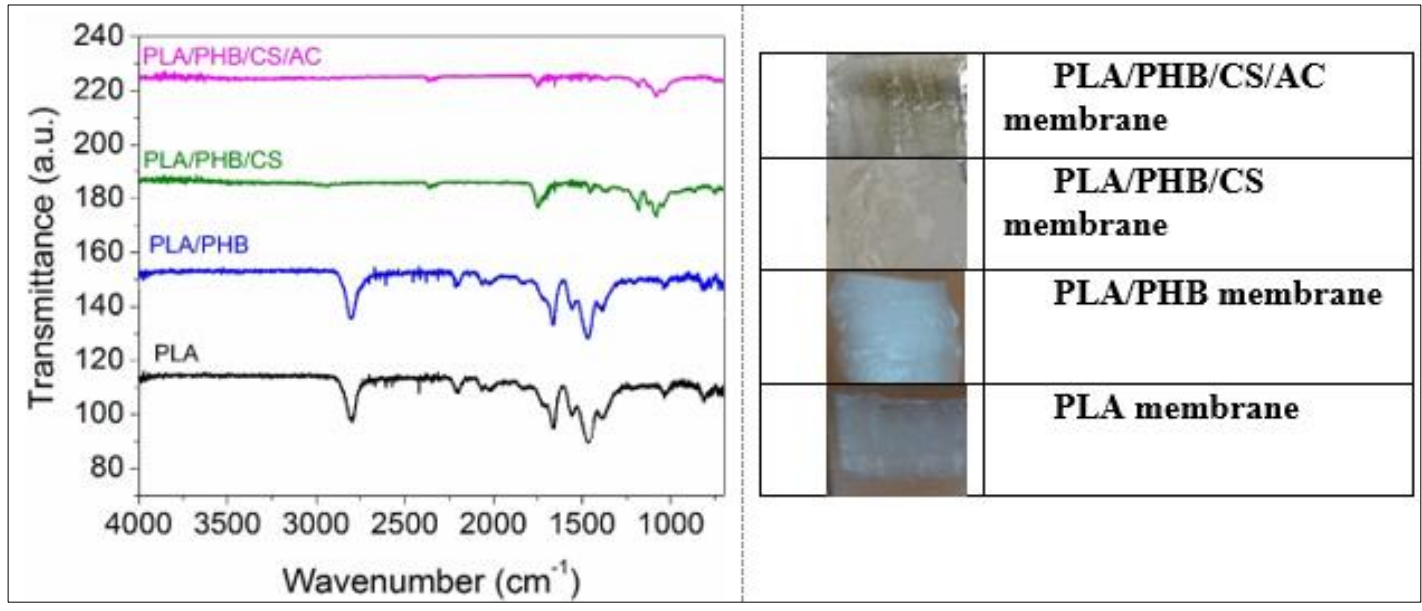

Figure 2. ATR-FTIR spectra and the optical images for the electrospun polymeric membranes:

PLA membrane; PLA/PHB membrane, PLA/PHB/CS membrane, and PLA/PHB/CS/AC membrane

The FT-IR spectrum for the PLA type membrane indicated the presence of the absorption bands at $1721 \mathrm{~cm}^{-1}$ attributed to the symmetrical vibration of the $\mathrm{C}=\mathrm{O}$ bond, a small shoulder at $1755 \mathrm{~cm}^{-1}$ related to the amorphous state of polyester, $2867 \mathrm{~cm}^{-1}$ and $2941 \mathrm{~cm}^{-1}$ due to the symmetrical and antisymmetric stretching vibration of the $\mathrm{C}-\mathrm{H}$ bond. In the case of PLA/PHB membrane, the same absorption peaks like PLA membrane are observed, highlighting the polyester nature of PHB. The presence of the absorption band at $1748 \mathrm{~cm}^{-1}$ attributed to the stretching vibration of the $\mathrm{C}=\mathrm{O}$ bond of the ester group [34], and $1458 \mathrm{~cm}^{-1}$ assigned to the bending vibration of the $\mathrm{CH}_{3}$ group from polyesters [35] are observed in the case of PLA/PHB/CS and PLA/PHB/CS/AC membranes. The presence of chitosan was highlighted by the absorption peaks due to the acetamide groups located at $1382 \mathrm{~cm}^{-1}$ [36] for PLA/PHB/CS and $1378 \mathrm{~cm}^{-1}$ in the case of PLA/PHB/CS/AC. However, the functional groups from polyesters can not be observed in the case of the coating PLA/PHB membrane with CS and CS/AC, respectively, maybe due to the thick coating layers.

\subsection{Differential Scanning Calorimetry (DSC)}

Figure 3 shows the DSC curves for PLA and PLA/PHB electrospun polymeric membranes.

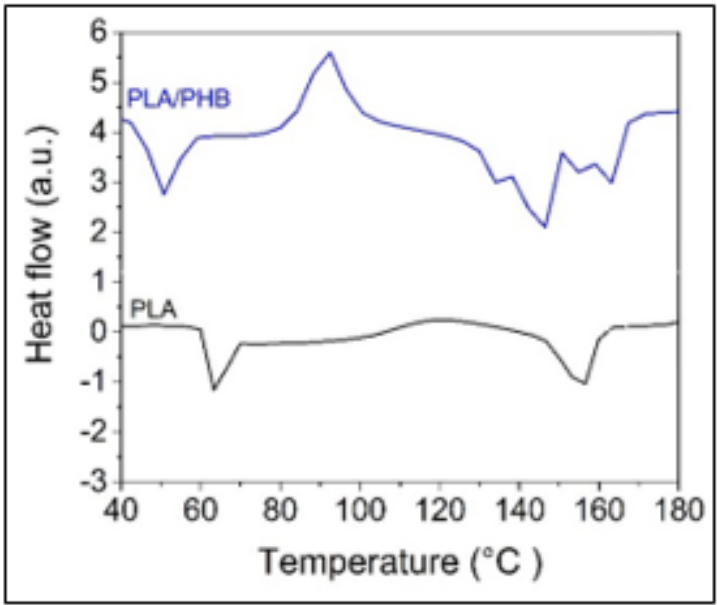

Figure 3. DSC curves for PLA and PLA/PHB membranes (first heating run)

Nonwoven PLA membrane is characterized by a glass transition temperature $(\mathrm{Tg})$ of $62^{\circ} \mathrm{C}$, a small cold crystallization temperature (Tcc) of $120^{\circ} \mathrm{C}$ and a melting temperature $(\mathrm{Tm})$ of $157^{\circ} \mathrm{C}$. Approximately the same DSC parameters were reported for PLA prepared by melt processing [37]. DSC curve for the PLA/PHB membrane shows one single Tg at $52^{\circ} \mathrm{C}$ meaning the miscibility of components and enhancing in the flexibility of polymeric chains compared with the PLA, and an evident Tcc at $92^{\circ} \mathrm{C}$. 
A similar decrease in Tg and Tcc compared with PLA was reported by Arrieta et al. 2015 [38] in the case of PLA/PHB (75:25) electrospun mat, explained by the capacity of PHB to re-crystallize the PLA matrix. The melting temperature for PLA/PHB membrane retains the characteristics of PLA and PHB respectively, showing one first maxim melting peak located at $148^{\circ} \mathrm{C}$ with a shoulder at $132^{\circ} \mathrm{C}$, associated to melting of PLA, followed by another at $167^{\circ} \mathrm{C}$ with a shoulder at $154^{\circ} \mathrm{C}$ due to the melting of PHB.

\subsection{Filtration of Suspended Solid Solution}

In order to test the PLA and PLA/PHB polymeric membranes for retaining suspensions from the water, $1 \%$ fine sand solution was prepared.

According to the data showed in Table 3 it is observed that the PLA/PHB polymeric membrane allows the filtration of distilled water with the highest flow $(0.1595 \mathrm{~mL} / \mathrm{s})$, while the PLA polymeric membrane recorded a flow of $0.1079 \mathrm{~mL} / \mathrm{s}$. This could be explained by the flexibility and, maybe, the thickness of the electrospun polymeric membranes. In the case of the solid suspension filtration, the filter flow is equal for these membranes types $(0.053 \mathrm{~mL} / \mathrm{s})$, but the amount of retained sand was different. It is possible that some pores of the PLA membrane to be clogged with fine sand particles, which led to a less amount of contaminant retained $(248 \mathrm{mg})$. The filtration efficiency was high when used filter membranes based on PLA. After filtering the contaminant solutions with $1 \%$ sand, it was found that the pores of the membranes were clogged, which indicates that the filtrate solution contains particles equal in size to the pores of the membrane. Also, larger solid particles were retained on the surface of the filter. However, the membrane architecture of PLA and PLA/PHB allows a good pore distribution such that to obtain efficient filtration of suspended solid solution. The utility of bio-based polymeric membranes can be extended to other suspensions present in water, as well to the retention of microplastics from rivers.

Table 3. Flow rate and filtration efficiency of a $1 \%$ solid suspension solution using PLA and PLA/PHB polymer membranes

\begin{tabular}{|c|c|c|c|c|}
\hline \multirow{2}{*}{$\begin{array}{c}\text { Electrospun bio- } \\
\text { based membrane }\end{array}$} & Distilled water & \multicolumn{3}{|c|}{$\mathbf{1 \%}$ solid suspension solution } \\
\cline { 2 - 5 } & Filter flow $(\mathrm{mL} / \mathrm{s})$ & Filter flow $(\mathrm{mL} / \mathrm{s})$ & $\begin{array}{c}\text { Amount of sand } \\
\text { suspension retained } \\
(\mathrm{mg})\end{array}$ & Filter efficiency (\%) \\
\hline PLA & 0.1079 & 0.053 & 248 & 99.2 \\
\hline PLA/PHB & 0.1595 & 0.053 & 251 & 98.4 \\
\hline
\end{tabular}

Table 4 shows the physical characteristics of filter solutions through polymeric membranes: $p \mathrm{H}$, electroconductivity and total soluble salt content. The water resulting from the retention of the suspended solid solution is characterized by a $p \mathrm{H}$ value between 5.6 and 6.3 , very close to the value of distilled water $(p \mathrm{H}$ value $\sim 6)$.

Table 4. Characteristics of solutions filtered through polymeric membranes.

\begin{tabular}{|c|c|c|c|}
\hline $\begin{array}{c}\text { Electrospun bio-based } \\
\text { membrane }\end{array}$ & $\begin{array}{c}\text { Filtered } \\
\text { solution } \mathbf{p H}\end{array}$ & $\begin{array}{c}\text { Electroconductivity of the } \\
\text { filtered solution }(\boldsymbol{\mu S} / \mathbf{c m})\end{array}$ & $\begin{array}{c}\text { Total content of } \\
\text { soluble salts }(\mathbf{m g} / \mathbf{L})\end{array}$ \\
\hline PLA & 5.6 & 11.65 & 7.456 \\
\hline PLA/PHB & 6.3 & 18.05 & 11.55 \\
\hline
\end{tabular}

Compared to the conductivity value recorded by the distilled water sample $(2.67 \mu \mathrm{S} / \mathrm{cm})$, from Table 4 it is observed that the solutions obtained by filtration with the help of polymeric membranes had a higher conductivity, due to the dissolution of some existing salts. The total content of soluble salts is in good correlation with the electroconductivity of the filtered solutions. The total soluble salt content is highest in the case of the PLA/PHB polymer membrane $(11.55 \mathrm{mg} / \mathrm{L})$, in correlation with the filtration 
efficiency shown in Table 3. The transmittance of water resulted from the filtration process with biobased membranes is shown in Figure 4.

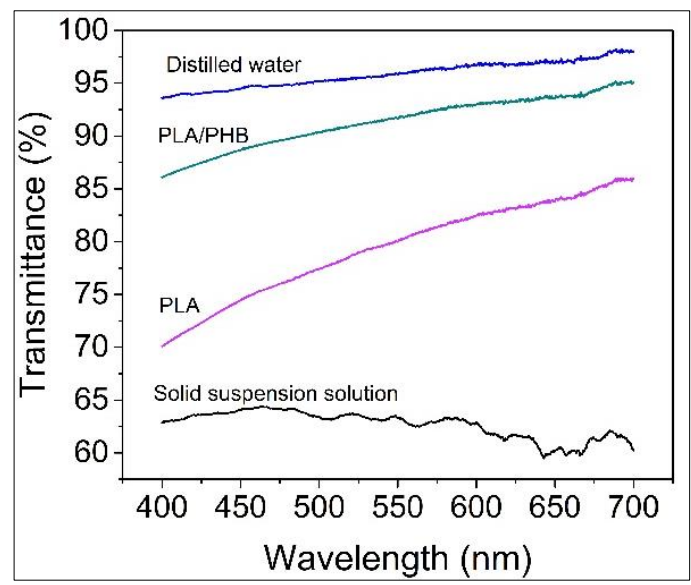

Figure 4. Transmittance for PLA and PLA/PHB membranes compared with distilled water and solid suspension solution

In all membranes tested, the resulting water was clearly, which reveals the importance of the filtration process (Figure 4).

\subsection{Removal efficiency}

In order to evaluate the adsorption capacity, the two membranes were tested in aqueous solutions with $\mathrm{Pb}$ as heavy metal with high impact on aquatic environment. The role of membranes was established by analyses before and after immersion into solution with $1 \mathrm{mg} / \mathrm{L} \mathrm{Pb}$ (II). The pollutant removal (as percentage) during 120 min contact time is presented in Figure 5.

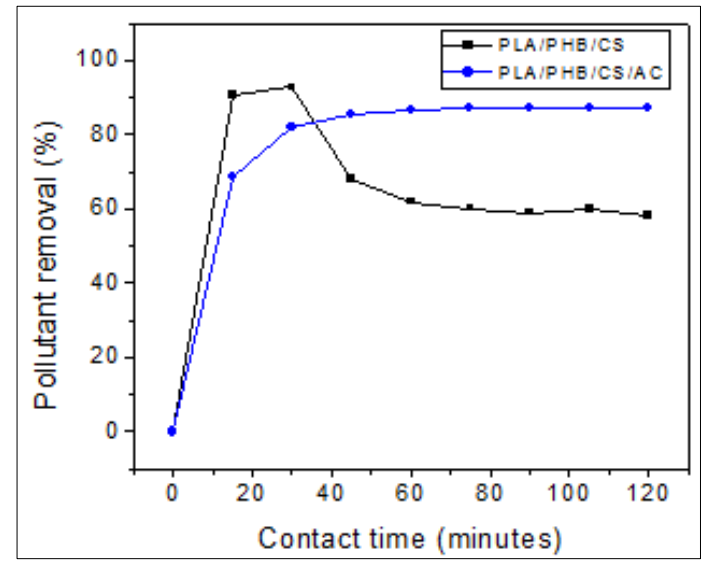

Figure 5. Effect of contact time on the adsorption of $\mathrm{Pb}$ (II) ions by the nonwoven PLA/PHB/CS and $\mathrm{PLA} / \mathrm{PHB} / \mathrm{CS} / \mathrm{AC}$ membranes. Experimental conditions: the amount of adsorbent of $500 \mathrm{mg}$ was dispersed into $100 \mathrm{~mL}$ solution of $\mathrm{Pb}$ (II) pollutant at $1 \mathrm{mg} / \mathrm{L}$ under gentle stirring conditions at room temperature and $200 \mathrm{rpm}$, and at maximum $120 \mathrm{~min}$ contact time

After $15 \mathrm{~min}$, the highest pollutant retention efficiency of the PLA/PHB/CS adsorbent material (94.6\%) was observed, after that it decreased with the increasing contact time up to $120 \mathrm{~min}$, to about $53 \%$ (Figure 5). This behaviour can be explained by the competition between $\mathrm{Pb}$ (II) ions to fill the vacancies sites in the first $15 \mathrm{~min}$ and the repulsive force that decreases the adsorption rate of $\mathrm{Pb}$ (II) from 30 to $120 \mathrm{~min}$. In the case of PLA/PHB/CS/AC membrane, $>60 \%$ efficiency is reached in the first $15 \mathrm{~min}$, following that the equilibrium to be reached after $50 \mathrm{~min}$ (the maximum value being of 85\%). This demonstrates the complementary performance and synergy occurred between the chitosan and activated carbon, as well as the role of nanofiber dimensions on the heavy metal adsorption process. The results indicate possibility of membrane use in $\mathrm{Pb}$ retention and removal from aqueous systems, thus future experiments will be developed for different concentrations of $\mathrm{Pb}$ and membranes quantities in order to be established the retention mechanism and maximum retained $\mathrm{Pb}$ quantity onto studied membranes. 


\section{Conclusions}

Symmetric and asymmetric bio-based polymeric membranes were fabricated by the electrospinning process. The efficiency of the PLA and PLA/PHB membranes was proved by performing the filtration of a solid suspension solution, and the adsorption of $\mathrm{Pb}$ (II) in the case of $\mathrm{PLA} / \mathrm{PHB} / \mathrm{CS}$ and $\mathrm{PLA} / \mathrm{PHB} / \mathrm{CS} / \mathrm{AC}$ membranes.

SEM analysis revealed that the thickness of fibers was of maximum $400 \mathrm{~nm}$, and the size of the membrane pores was $\sim 20 \mu \mathrm{m}$, which is suitable for retaining of solid suspension from water with the same dimension. The thermal transitions highlighted by the DSC analysis show the characteristic peaks of polyesters and the improved in the flexibility in the case of PLA/PHB membrane. The FTIR results confirmed the chemical structure of the membranes.

The results showed that the PLA and PLA/PHB polymeric membranes led to the filtration efficiency of 99.2 and $98.4 \%$, respectively for $1 \%$ sand solution and good physical characteristics of the filtered solutions. The PLA/PHB/CS membrane recorded $94.6 \%$ efficiency for removing $\mathrm{Pb}$ (II) from wastewater for the first $15 \mathrm{~min}$, while the PLA/PHB/CS/AC membrane reached $85 \%$ efficiency after $50 \mathrm{~min}$. The electrospun polymeric biomembranes are promising for further investigated at industrial scale to replace membranes made of petrochemical plastic materials.

Acknowledgments: The work has been funded by the European Union through POC Program, Project ID: P_40_253, Contract 130/23.09.2016, SMIS 105558, Subsidiary Contract 5048/23.03.2018, and Subsidiary Contract 25501/18.12.2018. The FTIR analysis on INTERSPEC 200-X Spectrophotometer was possible due to European Regional Development Fund through Competitiveness Operational Program 2014-2020, Priority axis 1, Project No. P_36_611, MySMIS code 107066, Innovative Technologies for Materials Quality Assurance in Health, Energy and Environmental - Center for Innovative Manufacturing Solutions of Smart Biomaterials and Biomedical Surfaces INOVABIOMED.

\section{References}

1. WARSinger, D. M., CHAKRABORTY, S., TOW, E. W., PluMlEE, M. H., BELlONA, C., LOUTATIDOU, S., LEILA KARIMI, ANNE M. MIKELONIS,ANDREA ACHILLI, ABBAS GHASSEMIG LOKESH P. PADHYE, SHANE A. SNYDER, STEFANO CURCIO, CHAD D. VECITIS, HASSAN A. ARAFAT, LIENHARD, J. H., A review of polymeric membranes and processes for potable water reuse, Progress in Polymer Science, 81, 2018, 209-237.

2. BODZEK, M., Membrane technologies for the removal of micropollutants in water treatment, Advances in Membrane Technologies for Water Treatment, 2015, 465-517.

3. LUO, Y., GUO, W., NGO, H. H., NGHIEM, L. D., HAI, F. I., ZHANG, J., LING, S. WANG, X. C., A review on the occurrence of micropollutants in the aquatic environment and their fate and removal during wastewater treatment, Science of The Total Environment, 473-474, 2014, 619-641.

4. EL-HADI, A. M., ALAMRI, H. R., The New Generation of Biomembrane with Green Technologies for Wastewater Treatment, Polymers, 10, 2018, 1174.

5. AO, C., YUAN, W., ZHAO, J., HE, X., ZHANG, X., LI, Q., XIA, T., ZHANG, W., LU. C., Superhydrophilic graphene oxide @ electrospun cellulose nanofiber hybrid membrane for highefficiency oil / water separation, Carbohydrate Polymers, 175, 2017, 216-222.

6. ZAVASTIN, D. E., GHERMAN, S., CRETESCU, I., Removal of Direct Blue Dye from Aqueous Solution Using NewPolyurethane - Cellulose Acetate Blend Micro - filtration Membrane, Rev. Chim., 63(10), 2012, 1075-1078.

7. SURAWANVIJIT, S., LIU, H. H, KIM, M., COHEN, Y., Removal of Metal Oxide Nanoparticles from Aqueous Suspensions, Separation Science and Technology, 49(2), 2014, 161-170.

8. EL-HADI, A. M., ALAMRI, H. R., The New Generation of Biomembrane with Green Technologies for Wastewater Treatment, Polymers, 10, 2018, 1174.

9. CHEN, K., CHOU, W., LIU, L., CUI, Y., XUE, P., JIA, M., Electrochemical Sensors Fabricated by 
Electrospinning Technology: An Overview, Sensors, 19, 2019, 3676.

10. MERCANTE, L. A., SCAGION, V. P., Migliorini, F. L., MATTOSO, L. H. C., CORREA, D. S., Electrospinning-based (bio)sensors for food and agricultural applications: A review, TrAC Trends in Analytical Chemistry, 91, 2017, 91-103.

11. NAGATA, S., ATKINSON, G. M., PESTOV, D., TEPPER, G. C., MCLESKEY, J. T., Electrospun Polymer-Fiber Solar Cell, Advances in Materials Science and Engineering, 2013, 1-6.

12. RÂPĂ, M., GAIDĂU, C., STEFAN, L.M., MATEI, E., NICULESCU, M., BERECHET, M. D., STANCA, M., TABLET, C., TUDORACHE, M., GAVRILĂ, R., PREDESCU C., VIDU. R., New Nanofibers Based on Protein By-Products with Bioactive Potential for Tissue Engineering, Materials, 13(14), 2020, 3149.

13. BALUSAMY, B., CELEBIOGLU, A., SENTHAMIZHAN, A., UYAR, T., Progress in the design and development of "fast-dissolving" electrospun nanofibers based drug delivery systems - A systematic review, Journal of Controlled Release, 326, 2020, 482-509.

14. MANEA, L. R., BERTEA, A., NECHITA, E., POPESCU, C. V., SANDU, I., Mathematical Model of the Electrospinning Process I. Effect of the distance between electrodes on the electrospun fibers diameter, Rev. Chim., 67(7), 2016, 1284-1289.

15.WANG, X., HSIAO, S. B., Electrospun nanofiber membranes, Current Opinion in Chemical Engineering, no. 12, 2016, 62-81.

16.KHULBE, K.C., MATSUURA, T., Removal of heavy metals and pollutants by membrane adsorption techniques, Appl. Water Sci., 8, 2018, 19.

17.ZANDER, E. N., GILLAN, M., SWEETSER, D., Recycled PET Nanofibers for Water Filtration Applications, Materials, 9, 2016, 247.

18.VIADERO, R. C., NOBLET, J. A., Membrane filtration for removal of fine solids from aquaculture process water, Aquacultural Engineering, 26(3), 2002, 151-169.

19.KAMPALANONWAT, P., SUPAPHOL, P., Preparation and Adsorption Behavior of Aminated Electrospun Polyacrylonitrile Nanofiber Mats for Heavy Metal Ion Removal, ACS Applied Materials \& Interfaces, 2, no. 12, 2010, 3619-3627.

20.HENDRICK, E., FREY, M., Increasing Surface Hydrophilicity in Poly(Lactic Acid) Electrospun Fibers by Addition of PLA-b-PEG Co-Polymers, Journal of Engineered Fibers and Fabrics, no.2, 2014. 21.CORREIA, D. M., RIBEIRO, C., FERREIRA, J. C. C., BOTELHO, G., RIBELlES, J. L. G., MÉNDEZ, S. L., SENCADAS, V., Influence of electrospinning parameters on poly(hydroxybutyrate) electrospun membranes fiber size and distribution, Polym. eng. sci., 54, 2014, 1608-1617.

22.PETERSEN, K., NIELSEN, P., OLSEN, M., Physical and mechanical properties of biobased materials-starch, polylactate and polyhydroxybutyrate, Starch, 53, 2001, 356-361.

23. RAPA, M., DARIE-NITA, R. N., VASILE, C., Influence of plasticizers over some physico-chemical properties of PLA, Mater. Plast., 54(1), 2017, 73-78.

24.EL-HADI, A. M., ALAMRI, H. R., The New Generation from Biomembrane with Green Technologies for Wastewater Treatment, Polymers, 10, 2018, 1174.

25. EANG, C., OPAPRAKASIT, P., Electrospun Nanofibers with Superhydrophobicity Derived from Degradable Polylactide for Oil/Water Separation Applications, J. Polym. Environ., 28, 2020, 1484 1491.

26. FABRA, M. J., LOPEZ-RUBIO, A., LAGARON, J. M., Food Hydrocolloids, 39, 2014, 77-84.

27. LECETA, I., GUERRERO, P., CABEZUDO, S., DE LA CABA, K., Journal of Cleaner Production, 41, 2013, 312-318.

28. ROGOVINA, S., ZHORINA, L., GATIN, A., PRUT, E., KUZNETSOVA, O., YAKHINA, A., OLKHOV, A., SAMOYLOV, N., GRISHIN, M., IORDANSKII, A., BERLIN, A., Biodegradable Polylactide-Poly(3-Hydroxybutyrate) Compositions Obtained via Blending under Shear Deformations and Electrospinning: Characterization and Environmental Application, Polymers, 12(5), 2020, 1088.

29. DASH, M., CHIELLINI, F., OTTENBRITE, R. M., CHIELLINI. E., Chitosan-A versatile semisynthetic polymer in biomedical applications, Progress in Polymer Science, 36(8), 2011, 981-1014. 
30. JÓŹWIAK, T., FILIPKOWSKA, U., SZYMCZYK, P., RODZIEWICZ, J., MIELCAREK, A., Effect of ionic and covalent crosslinking agents on properties of chitosan beads and sorption effectiveness of Reactive Black 5 dye, Reactive and Functional Polymers, 114, 2017, 58-74.

31. MATEI, E., PREDESCU, A. M., RÂPĂ, M., TARCEA, C., PANTILIMON, C. M., FAVIER, L., BERBECARU, A. C., SOHACIU, M., PREDESCU C., Removal of Chromium(VI) from Aqueous Solution Using a Novel Green Magnetic Nanoparticle - Chitosan Adsorbent, Analytical Letters, 52 ( 15) 2019, 2416-2438.

32. PREDESCU, A. M., MATEI, E., RÂPĂ, M., PANTILIMON, C., COMAN, G., SAVIN, S., POPA, E. E., PREDESCU, C., Adsorption of Lead(II) from Aqueous Solution Using Chitosan and Polyvinyl Alcohol Blends, Analytical Letters, 52 (15) 2365-2392.

33.WANG, X., HSIAO, S. B., Electrospun nanofiber membranes, Current Opinion in Chemical Engineering (12) 2016, 62-81.

34. ARRIETA, M. P., LÓPEZ, J., LÓPEZ, D., KENNY, J. M., PEPONI, L., Development of flexible materials based on plasticized electrospun PLA-PHB blends: Structural, thermal, mechanical and disintegration properties, European Polymer Journal, (73, 2015, 433-446.

35. RÂPĂ, M., DARIE-NIŢĂ, R.N., GROSU, E., TĂNASE, E. E., TRIFOI, A. R., PAP, T., VASILE, C., Effect of plasticizers on melt processability and properties of PHB, Journal of Optoelectronics and Advanced Materials, 17, no. 11-12, 2015, 1778-1784.

36. RAPA, M., MITELUT, A. C., TANASE, E. E., GROSU, E., POPESCU, P., POPA, M. E., ROSNES, J. T., SIVERTSVIK, M., DARIE-NIŢĂ, R. N., VASILE, C., Influence of chitosan on mechanical, thermal, barrier and antimicrobial properties of PLA-biocomposites for food packaging, Composites Part B Engineering, no. 102, 2016, 112-121.

37. ROGOVINA, S., ZHORINA, L., GATIN, A., PRUT, E., KUZNETSOVA, O., YAKHINA, A., OLKHOV, A., SAMOYLOV, N., GRISHIN, M., IORDANSKII, A., BERLIN, A., Biodegradable Polylactide-Poly(3-Hydroxybutyrate) Compositions Obtained via Blending under Shear Deformations and Electrospinning: Characterization and Environmental Application, Polymers, 12(5), 2020, 1088.

38. ARRIETA, M. P., LÓPEZ, J., LÓPEZ, D., KENNY, J. M., PEPONI, L, Development of flexible materials based on plasticized electrospun PLA-PHB blends: Structural, thermal, mechanical and disintegration properties, European Polymer Journal, 73, 2015, 433-446

$\overline{\text { Manuscript received: } 4.09 .2020}$ 